\title{
KEDUDUKAN BENDAHARA PASCA UNDANG-UNDANG NOMOR 1 TAHUN 2004 TENTANG PERBENDAHARAAN NEGARA
}

Febie Saputra

Sekretariat Direktorat Jenderal Perbendaharaan

Alamat Korespondensi: fobey.saputra@gmail.com

\section{INFORMASI ARTIKEL}

Diterima Pertama

10 Juni 2016

Dinyatakan Diterima

11 November 2016

KATA KUNCI:

State Financial Management, State Treasury, State Financial Audit, Good Governance, Functional Role.

KLASIFIKASI JEL:

H83.

\begin{abstract}
ABSTRAK
The three packages of law on state financial management (Law No. 17 of 2003 on State Finance, Law No. 1 of 2004 on State Treasury and Law No. 15 of 2004 on State Financial Audit) have some fundamental differences from previous regulations. One of them is to post State Treasurer as a functional role. The government conducts a central role in achieving good governance in the implementation of the state budget. Article 23 verse (1) of the 1945 Constitution of the Republic of Indonesia provides a strong legal basis to implement the principles of good governance. In managing the state budget, one mechanism to implement good governance is to improve state treasurer professionalism as a functional role; unfortunately, the research shows that more sustained and coherent efforts are needed to realize this.
\end{abstract}

Apabila dibandingkan dengan peraturan perundang-undangan sebelumnya, ketiga paket undang-undang pengelolaan keuangan negara, yaitu Undang-Undang Nomor 17 Tahun 2003 tentang Keuangan Negara, Undang Nomor 1 Tahun 2004 tentang Perbendaharaan Negara dan Undang-Undang Nomor 15 Tahun 2004 tentang Pemeriksaan Pengelolaan dan Tanggung Jawab Keuangan Negara, memiliki beberapa perbedaan yang cukup mendasar. Salah satu di antaranya adalah jabatan bendahara sebagai jabatan fungsional. Pemerintah memegang peran utama dalam mewujudkan good governance dalam pelaksanaan anggaran belanja negara. Pasal 23 ayat (1) Undang-Undang Dasar Negara Republik Indonesia 1945 telah memberikan landasan hukum yang kuat dalam rangka penerapan prinsip-prinsip good governance. Dalam mengelola APBN, salah satu mekanisme untuk mewujudkan good governance adalah dengan meningkatkan profesionalisme bendahara negara sebagai tenaga fungsional; namun demikian, penelitian menunjukkan bahwa upaya terkait dan berkelanjutan dibutuhkan untuk merealisasikan maksud tersebut. 


\section{PENDAHULUAN}

\subsection{Latar Belakang}

Konstitusi memiliki peran sentral dalam sistem tata negara, kedudukannya merupakan sesuatu yang penting bagi setiap bangsa dan negara. Konstitusi adalah segala ketentuan dan aturan mengenai ketatanegaraan (Undang-Undang Dasar, dan sebagainya), atau Undang-Undang Dasar suatu negara. ${ }^{1}$ Menurut Black's Law Dictionary, yang dimaksud dengan konstitusi (constitution) adalah:

"The organic and fundamental law of a nation or a state, which may be written or unwritten. Establishing the character and conception of its government. Laying the basic principles to which its internal life its to be conformed, organizing the government, and regulating, distributing, and limitng the function of its different departments, and prescribing the extent and manner of the exercise of sovereign powers". ${ }^{2}$

Konstitusi pada Negara Kesatuan Republik Indonesia disebut sebagai Undang-Undang Dasar Negara Republik Indonesia 1945 (selanjutnya cukup disebut dengan UUD 1945). Indonesia sebagai negara hukum atau Rechtstaat, tidak saja mengutamakan kesejahteraan rakyat, akan tetapi lebih dari itu, yakni membentuk manusia Indonesia seutuhnya. Dalam upaya mewujudkan tujuan tersebut, negara telah melaksanakan kegiatan pemerintahan secara rutin, konsepsional dan konsisten, melalui pembangunan. Pembangunan hakikatnya adalah upaya mewujudkan tujuan nasional bangsa Indonesia yang maju, mandiri, sejahtera, berkeadilan, berdasarkan keimanan dan ketakwaan kepada Tuhan Yang Maha Esa. Di dalam alinea keempat Pembukaan UUD 1945 disebutkan bahwa tujuan negara Indonesia adalah untuk membentuk suatu Pemerintah Negara Indonesia yang melindungi segenap bangsa Indonesia dan seluruh tumpah darah Indonesia dan untuk memajukan kesejahteraan umum, mencerdaskan kehidupan bangsa, dan ikut melaksanakan ketertiban dunia yang berdasarkan kemerdekaan, perdamaian abadi dan keadilan sosial.

Berdasarkan tujuan negara tersebut di atas, pemerintah mempunyai tanggung jawab yang besar dalam meningkatkan kesejahteraan masyarakatnya. Dalam rangka mencapai tujuan tersebut, pemerintah telah melakukan berbagai upaya, diantaranya adalah dengan reformasi di bidang keuangan negara.

1 Dahlan Thaib, et al., Teori dan Hukum Konstitusi (Jakarta, Raja Grafindo Persada, 2006), hlm. 1.

2 Henry Campbell Black, Black's Law Dictionary with Pronunciations (USA, Fifth Edition, West Publishing co.st. Paul Minn, 1979), hlm. 282.
Pengelolaan keuangan di suatu negara dipengaruhi oleh peraturan perundang-undangan yang mengaturnya. Sebagai salah satu metode untuk mengetahui transparansi dan akuntabilitas pengelolaan keuangan pada suatu negara, perlu dilakukan kajian terhadap peraturan perundangundangan yang mengaturnya. Seperti halnya di Indonesia, sejak merdeka hingga tahun 2003 belum memiliki peraturan perundang-undangan yang secara komprehensif dapat memberikan regulasi dalam pengelolaan keuangan negara yang transparan dan akuntabel.

Pengelolaan keuangan negara pada waktu itu masih didasarkan pada undang-undang produk kolonial yang disebut dengan Indische Comptabiliteitswet (ICW) Staatsblad Tahun 1925 Nomor 448 atau Undang-Undang Perbendaharaan Indonesia (selanjutnya cukup disebut dengan ICW 1925); sebagaimana telah beberapa kali diubah, terakhir diubah dengan Undang-Undang Nomor 9 Tahun 1968 tentang Perubahan Pasal 7 Indische Comptabiliteitswet (Staatsblad 1925 Nomor 448) sebagaimana telah diubah dengan Undang-Undang Nomor 3 Drt. Tahun 1954.

Harapan akan lahirnya pengelolaan keuangan negara yang lebih baik muncul pada saat terbitnya Undang-Undang Nomor 17 Tahun 2003 tentang Keuangan Negara (selanjutnya cukup disebut dengan UU Keuangan Negara)

Pemerintah memegang peran utama dalam mewujudkan good governance dalam pelaksanaan Anggaran Pendapatan dan Belanja Negara. Pasal 23 ayat (1) UUD 1945 telah memberikan landasan hukum yang kuat dalam rangka penerapan prinsipprinsip good governance. Anggaran Pendapatan dan Belanja Negara (APBN) sebagai wujud dari pengelolaan keuangan negara ditetapkan setiap tahun dengan undang-undang, dilaksanakan secara terbuka dan bertanggung jawab untuk sebesarbesarnya kemakmuran rakyat. Dengan demikian, pelaksanaan APBN yang bertujuan untuk meningkatkan sebesar-besarnya kemakmuran rakyat, dengan didasarkan pada persamaan kedudukan atas kemajemukan/ pluralitas masyarakat Indonesia.

Sebagai penjabaran prinsip akuntabilitas dan transparansi sebagaimana telah ditetapkan dalam UUD 1945, UU Keuangan Negara menjabarkannya ke dalam asas-asas umum yang telah lama dikenal dalam pengelolaan kekayaan negara. Asas-asas tersebut diantaranya: asas tahunan, asas universalitas, asas kesatuan dan asas spesialitas. Dalam perkembangannya, dikenal pula asas-asas yang mencerminkan penerapan kaidah-kaidah yang baik (best practices) dalam pengelolaan keuangan negara, antara lain: akuntabilitas, orientasi pada hasil, profesionalitas, proporsionalitas, keterbukaan dalam pengelolaan 
keuangan negara, dan pemeriksaan keuangan oleh badan pemeriksa yang bebas dan mandiri.

Keberadaan UU Keuangan Negara memiliki peran yang penting dalam mendorong diterbitkannya perangkat hukum pengelolaan keuangan negara lebih lanjut. Diantaranya, diterbitkan Undang-Undang Nomor 1 Tahun 2004 tentang Perbendaharaan Negara (UU Perbendaharaan Negara) dan Undang-Undang Nomor 15 Tahun 2004 tentang Pemeriksaan Pengelolaan dan Tanggung jawab Keuangan Negara. Dengan tiga undang-undang tersebut, pemerintah telah memiliki pondasi yang cukup guna melakukan pengelolaan keuangan negara yang lebih sesuai dengan tuntutan jaman.

Jika dibandingkan dengan peraturan perundang-undangan sebelumnya, ketiga paket undang-undang pengelolaan keuangan negara tersebut memiliki beberapa perbedaan yang cukup mendasar dan bahkan terdapat hal baru yang sebelumnya tidak dikenal. Salah satu di antaranya adalah jabatan bendahara sebagai jabatan fungsional.

Fungsionalisasi jabatan bendahara tidak dikenal dalam peraturan perundang-undangan pengelolaan keuangan negara yang lama. Hal ini menunjukkan begitu pentingnya pengelolaan keuangan pada tingkat Satuan Kerja sehingga harus dikelola oleh seorang pejabat fungsional, bukan lagi sebagai pekerjaan tambahan ataupun sampingan.

Sejalan dengan perkembangan kebutuhan pengelolaan keuangan negara, semakin dibutuhkan peningkatan fungsi perbendaharaan dalam rangka pengelolaan sumber daya keuangan pemerintah yang terbatas secara efisien. Fungsi perbendaharaan tersebut meliputi perencanaan kas yang baik, pencegahan agar tidak terjadi kebocoran dan penyimpangan, dan pemanfaatan idle cash untuk meningkatkan nilai tambah sumber daya keuangan.

\subsection{Rumusan Masalah}

Berdasarkan uraian latar belakang di atas, maka dapat dirumuskan isu hukum sebagai berikut:

a. Jabatan fungsional dalam konteks kedudukan bendahara;

b. Prinsip good governance dalam pengelolaan keuangan negara.

\subsection{Tujuan Penelitian}

Penelitian ini dari sisi teoritis bertujuan untuk menganalisis dasar pemikiran dan makna bendahara, serta mengkaji dasar normatif dari prinsip good governance dalam pengelolaan keuangan negara. Selain itu, dari sisi praktis penelitian ini dimaksudkan untuk mendorong terwujudnya pembentukan jabatan fungsional bendahara.

\section{KERANGKA TEORI DAN PENGEM- BANGAN HIPOTESIS}

\subsection{Keuangan Negara}

Istilah keuangan negara terdapat dalam Bab VIII Hal Keuangan Pasal 23 Undang-Undang Dasar 1945 sebelum amandemen dan Pasal 23C UndangUndang Dasar Negara Republik Indonesia 1945 pasca amandemen ketiga (yang disahkan pada tanggal 10 November 2001). Dalam Pasal 23 Undang-Undang Dasar Negara Republik Indonesia Tahun 1945 sebelum amandemen diatur bahwa:

1. Anggaran Pendapatan dan Belanja Negara (APBN) ditetapkan tiap-tiap tahun dengan undang-undang. Apabila Dewan Perwakilan Rakyat (DPR) tidak menyetujui anggaran yang diusulkan pemerintah, maka pemerintah menjalankan anggaran tahun yang lalu.

2. Segala pajak untuk keperluan negara berdasarkan undang-undang.

3. Macam dan harga mata uang ditetapkan dengan undang-undang.

4. Hal keuangan negara selanjutnya diatur dengan undang-undang.

5. Untuk memeriksa tanggung jawab tentang keuangan negara, diadakan suatu Badan Pemeriksa Keuangan (BPK), yang peraturannya ditetapkan dengan undangundang. Hasil pemeriksaan itu diberitahukan kepada DPR.

Dalam uraian pasal dimaksud, definisi keuangan negara tidak disebutkan, demikian halnya di dalam penjelasannya. Dalam Pasal 23C Undang-Undang Dasar Negara Republik Indonesia 1945 pasca amandemen ketiga, juga belum memuat batasan yang jelas tentang substansi keuangan negara. Hal ini dapat dimengerti karena Undang-Undang Dasar Negara Republik Indonesia 1945 hanya memuat aturan yang pokok-pokok saja, sedangkan penjabaran lebih lanjut dilaksanakan melalui undang-undang dan peraturan pelaksanaannya.

Dalam berbagai literatur, istilah keuangan negara memiliki pengertian yang beragam. Dalam kepustakaan ilmu hukum, keuangan negara dalam bahasa Belanda dikenal dengan istilah geldmiddelen. Menurut P.H. Van der Kamp sebagaimana dijelaskan dalam Bohari (1995), Geldmiddelen mengandung pengertian: “... all de rechten die een geld swaarde vertegenwoordegen, Zoomede al hetgeen faan gelden goed tenge volge van die rechten is varkregen ...." (semua hak yang dapat dinilai dengan uang, demikian pula segala 
sesuatu yang dapat dijadikan milik negara menghubungkan dengan hak-hak tersebut). ${ }^{3}$

Menurut Achir (1975), pada prinsipnya keuangan negara mengandung 4 (empat) unsur, yaitu: a.Hak-hak negara; b.Kewajiban-kewajiban negara; c.Ruang lingkup keuangan negara; dan d.Aspek sosial ekonomis dari keuangan negara. ${ }^{4}$

Hak-hak negara dan kewajiban-kewajiban negara tersebut baru dapat dinilai dengan uang apabila dilaksanakan. Adapun hak-hak negara yang dapat dinilai dengan uang tersebut, antara lain:

a. Hak mengenakan pajak kepada warganya, yang pungutannya sekedar perlu atau berdasar undang-undang yang dapat dipaksakan, tanpa memberi imbalan secara langsung kepada orang yang dikenakan pajak;

b. Negara dapat mencetak uang kertas maupun logam (dilakukan oleh Bank Indonesia melalui Perum Peruri);

c. Hak negara untuk mengadakan pinjaman (hutang luar negeri, misalnya melalui CGI, World Bank, dan lain-lain).

Kewajiban negara yang dapat dinilai dengan uang antara lain:

a. Kewajiban menyelenggarakan tugas negara demi kepentingan masyarakat, seperti pemeliharaan keamanan dan ketertiban, perbaikan jalan raya, pembangunan jembatan, pelabuhan dan pengairan;

b. Kewajiban membayar atau hak-hak tagihan pemborong, setelah barang/ bangunan diterima dengan baik oleh instansi pemesan.

Sebenarnya, beberapa peraturan perundangundangan telah memberikan pengertian mengenai keuangan negara. Namun, peraturan perundangundangan tersebut tidak secara khusus mengatur mengenai keuangan negara.

Peraturan perundang-undangan yang memberikan pengertian mengenai keuangan negara, antara lain: Undang-Undang Nomor 17 Tahun 1965 tentang Penetapan Peraturan Pemerintah Pengganti Undang-Undang Nomor 6 Tahun 1964 tentang Pembentukan Badan Pemeriksaan Keuangan menjadi Undang-Undang. Di dalam Pasal 3 peraturan dimaksud, bahwa: "yang dimaksud dengan keuangan negara dalam undang-undang ini adalah segala kekayaan negara dalam bentuk apapun juga, baik terpisah maupun tidak."

3 H. Bohari, Hukum Anggaran Negara (Jakarta, Raja Grafindo Persada, 1995), hlm. 8.

4 M.N. Azny Achir, Masalah Pengurusan Keuangan Negara (Bandung, Yulianti, 1975), hlm. 19.
Undang-Undang Nomor 31 Tahun 1999 tentang Pemberantasan Tindak Pidana Korupsi, memberikan pengertian keuangan negara sebagai: seluruh kekayaan negara dalam bentuk apapun, yang dipisahkan atau yang tidak dipisahkan, termasuk didalamnya segala bagian kekayaan negara dan segala hak dan kewajiban yang timbul karena:

(a) berada dalam penguasaan, pengurusan, dan pertanggungjawaban pejabat lembaga negara, baik di tingkat pusat maupun di daerah;

(b) berada dalam penguasaan, pengurusan, dan pertanggungjawaban Badan Usaha Milik Negara/ Badan Usaha Milik Daerah, yayasan, badan hukum, dan perusahaan yang menyertakan modal negara, atau perusahaan yang menyertakan modal pihak ketiga berdasarkan perjanjian dengan negara.

Selanjutnya, pada tanggal 5 April 2003 dikeluarkan undang-undang yang secara khusus mengatur mengenai keuangan negara yaitu UU Keuangan Negara.

Menurut ketentuan dalam Pasal 1 angka 1 UU Keuangan Negara, mengatur bahwa yang dimaksud dengan keuangan negara adalah "semua hak dan kewajiban negara yang dapat dinilai dengan uang, serta segala sesuatu baik berupa uang maupun berupa barang yang dapat dijadikan milik negara berhubung dengan pelaksanaan hak dan kewajiban tersebut."

Dalam penjelasan UU Keuangan Negara disebutkan bahwa pengertian keuangan negara dapat dibedakan antara pengertian keuangan negara dalam arti luas dan pengertian keuangan negara dalam arti sempit. Pengertian keuangan negara dalam arti luas pendekatannya adalah dari sisi objek yang cakupannya sangat luas, dimana keuangan negara mencakup kebijakan dan kegiatan dalam bidang fiskal, moneter dan pengelolaan kekayaan negara yang dipisahkan. Sedangkan pengertian keuangan negara dalam arti sempit hanya mencakup pengelolaan keuangan negara subbidang pengelolaan fiskal saja.

\subsection{Bendahara}

Berdasarkan ICW Staatsblad Tahun 1925 Nomor 448, Pasal 77 ayat (1) mengatur ketentuan tentang bendahara, sebagai berikut:

Art. 77 (1): “Behoudens het bepaalde bij art. 67 Zijn de personen en administration van Landswege belast met het ontvangen, bewaren, betalen of afleveren van gelden en geldswaarden en het bij art. 55 bedoelde materieel, comptabel, en als zoodanig verplicht aan de betrokken Algemeene Rekenkamer rekening af te leggen van door hen gevoerd beheer."

(Pasal 77 (1): "Dengan tidak mengurangi ketentuan dalam pasal 67, maka orang-orang dan badan- 
badan yang oleh negara diserahi tugas penerimaan, penyimpanan, pembayaran atau penyerahan uang, atau surat-surat berharga dan barang-barang termaksud dalam Pasal 55, adalah bendahara dan dengan demikian, berkewajiban untuk mengirim kepada Dewan Pengawas Keuangan perhitungan mengenai pengurusan yang dilakukannya.") ${ }^{5}$

Pasal 35 ayat (2) UU Keuangan Negara, mengatur bahwa "Setiap orang yang diberi tugas menerima, menyimpan, membayar, dan/ atau menyerahkan uang atau surat berharga atau barang-barang negara adalah bendahara yang wajib menyampaikan laporan pertanggungjawaban kepada Badan Pemeriksa Keuangan."

Menurut ketentuan Pasal 1 angka 14 UU Perbendaharaan Negara, yang dimaksud dengan bendahara adalah "setiap orang atau badan yang diberi tugas untuk dan atas nama negara/ daerah, menerima, menyimpan, dan membayar/ menyerahkan uang atau surat berharga atau barang-barang negara/ daerah."

Dalam rangka pelaksanaan tugas pengelolaan keuangan negara, ada tiga pembagian bendahara, yaitu bendahara umum, bendahara penerimaan dan bendahara pengeluaran. Di dalam penelitian ini, apabila hanya disebutkan kata "bendahara" berarti mengacu pada kata "bendahara pengeluaran".

\subsection{Jabatan Fungsional}

Jabatan fungsional pada hakekatnya adalah jabatan teknis yang tidak tercantum dalam struktur organisasi, namun sangat diperlukan dalam tugas-tugas pokok organisasi pemerintah.

Produk hukum yang mengatur pengangkatan seseorang dalam jabatan fungsional adalah Peraturan Pemerintah Republik Indonesia Nomor 16 Tahun 1994 tentang Jabatan Fungsional Pegawai Negeri Sipil dan Keputusan Presiden Republik Indonesia Nomor 87 Tahun 1999 tentang Rumpun Jabatan Fungsional Pegawai Negeri Sipil.

Jabatan fungsional PNS terdiri atas jabatan fungsional keahlian dan jabatan fungsional keterampilan. Hal tersebut sebagaimana diatur dalam pasal 2 ayat (2) Peraturan Pemerintah Republik Indonesia Nomor 16 Tahun 1994 tentang Jabatan Fungsional Pegawai Negeri Sipil.

Penetapan jabatan fungsional keahlian dan jabatan fungsional keterampilan ditetapkan dengan kriteria, sebagaimana diatur dalam pasal 3 Peraturan Pemerintah Republik Indonesia Nomor 16 Tahun 1994 tentang Jabatan Fungsional Pegawai Negeri Sipil, antara lain:

\footnotetext{
5 Arifin P. Soeria Atmadja, Mekanisme Pertanggungjawaban Keuangan Negara (Jakarta, Gramedia, 1986), hlm. 105.
}

a. Mempunyai metodologi, teknik analisis, teknik dan prosedur kerja yang didasarkan atas disiplin ilmu pengetahuan dan/ atau pelatihan tekhis tertentu dengan sertifikasi;

b. Memiliki etika profesi yang ditetapkan oleh organisasi profesi;

c. Dapat disusun dalam suatu jenjang jabatan berdasarkan:

1) Tingkat keahlian bagi jabatan fungsional keahlian;

2) Tingkat ketrampilan bagi jabatan fungsional ketrampilan;

d. Pelaksanaan tugas bersifat mandiri;

e. Jabatan fungsional tersebut diperlukan dalam pelaksanaan tugas pokok dan fungsi organisasi.

Menurut ketentuan Pasal 10 ayat (3) UU Perbendaharaan Negara, diatur bahwa "Bendahara Penerimaan dan Bendahara Pengeluaran sebagaimana dimaksud pada ayat (1) dan ayat (2) adalah Pejabat Fungsional."

Menurut ketentuan dalam Pasal 1 angka 1 Peraturan Pemerintah Republik Indonesia Nomor 16 Tahun 1994 tentang Jabatan Fungsional Pegawai Negeri Sipil, yang dimaksud dengan Jabatan Fungsional Pegawai Negeri Sipil adalah: “... kedudukan yang menunjukkan tugas, tanggung jawab, wewenang dan hak seseorang Pegawai Negeri Sipil dalam suatu satuan organisasi yang dalam pelaksanaan tugasnya didasarkan pada keahlian dan/ atau ketrampilan tertentu serta bersifat mandiri."

Walaupun UU Perbendaharaan Negara telah terbit tahun 2004, sampai saat ini dalam prakteknya bendahara belum dikategorikan sebagai jabatan fungsional seperti halnya jabatan guru, dosen, dan peneliti. Sebagai konsekuensinya, bendahara juga tidak mendapatkan tunjangan jabatan. Hal ini mengakibatkan keadaan ideal yang diinginkan oleh undang-undang tidak sepenuhnya dapat terwujud.

\subsection{Prinsip Good Governance}

Istilah governance muncul setelah berbagai lembaga pembiayaan internasional mempersyaratkan good governance dalam berbagai program bantuannya. Istilah good governance mulai populer di Indonesia mulai tahun 1990, yang terinspirasi oleh isu good governance yang banyak dibahas di negara-negara industri maju yang tergabung dalam OECD (Organization for Economic Cooperation and Development).

Oleh para teoritisi dan praktisi administrasi Indonesia, istilah good governance diterjemahkan sebagai: “... penyelenggaraan pemerintahan yang amanah, tata kepemerintahan yang baik, pengelolaan pemerintahan yang baik dan 
bertanggung jawab. Ada juga yang mengartikan secara sempit sebagai pemerintahan yang bersih."6

Perbedaan paling pokok antara konsep government dan governance terletak pada bagaimana cara penyelenggaraan otoritas politik, ekonomi dan administrasi dalam pengelolaan urusan suatu bangsa. Konsep government berkonotasi bahwa peranan pemerintah yang lebih dominan dalam penyelenggaran berbagai otoritas negara. Sedangkan dalam governance mengandung makna bagaimana cara suatu bangsa mendistribusikan kekuasaan dan mengelola sumberdaya dan berbagai masalah yang dihadapi masyarakat. Dengan kata lain, dalam konsep governance terkandung unsur demokratis, adil, transparan, rule of law, partisipatif dan kemitraan. ${ }^{7}$

Arti good dalam good governance sendiri mengandung dua pengertian, yaitu:

1. Nilai yang menunjung tinggi kehendak rakyat dan nilai yang meningkatkan kemampuan rakyat dalam mencapai tujuan kemandirian dan keadilan sosial

2. Aspek fungsional dari pemerintahan yang efektif dan efisien dalam pelaksanaan tugasnya untuk mencapai tujuan tersebut.

Wasistiono menyebutkan bahwa "dalam bahasa Indonesia, istilah governance ada yang menerjemahkan dengan tata pemerintahan dan ada pula yang menerjemahkan dengan kepemerintahan". ${ }^{8}$

Di dalam good governance terdapat tiga komponen atau pilar yang terlibat, yaitu:

a. good public governance yang merujuk pada lembaga pemerintahan (eksekutif, legislatif, dan yudisiil), sehingga dapat diartikan sebagai tata pemerintahan yang baik di lembagalembaga pemerintahan;

b. good corporate governance yang merujuk pada dunia usaha swasta, sehingga dapat diartikan sebagai tata kelola perusahaan yang baik;

c. civil society atau masyarakat sipil yang dapat mendukung terwujudnya good governance dan terutama good public governance.

Karena itu, good governance dapat diwujudkan apabila terjadi keseimbangan peran dari ketiga pilar yaitu: pemerintah, dunia usaha

6 Sofian Efendi, Membangun Budaya Birokrasi untuk Good Governance. Lokakarya Reformasi Birokrasi (Jakarta, Departemen Pemberdayaan Aparatur Negara, 2005), hlm. 2.

7 Ibid.

8 Sadu Wasistiono, Kapita Selecta Penyelenggaraan Pemerintahan Daerah, Edisi II (Bandung, Fokusmedia, 2003), hlm. 29. swasta, dan masyarakat. Ketiganya mempunyai peran masing-masing.

Dari keterangan tersebut di atas, dapat dikatakan bahwa prinsip-prinsip good governance antara lain terdiri dari:

a. Partisipasi masyarakat: semua warga masyarakat mempunyai suara dalam pengambilan keputusan, baik secara langsung maupun melalui lembaga-lembaga perwakilan yang sah yang mewakili kepentingan mereka. Partisipasi menyeluruh tersebut dibangun berdasarkan kebebasan berkumpul dan mengungkapkan pendapat, serta kepastian untuk berpartisipasi secara konstruktif;

b. Tegaknya supremasi hukum: keputusan, kebijakan pemerintah, organisasi, badan usaha berdasarkan hukum menimbulkan jaminan kepastian hukum dan rasa keadilan masyarakat terhadap setiap kebijaksanaan publik yang ditempuh; kerangka hukum harus adil dan diberlakukan tanpa pandang bulu, termasuk di dalamnya hukum-hukum yang menyangkut hak asasi manusia;

c. Transparasi: dapat diketahui oleh banyak pihak mengenai perumusan kebijaksanaan (politik) dari pemerintah, organisasi dan badan usaha. Dengan kata lain, segala tindakan dan kebijaksanaan pemerintah baik di pusat maupun di daerah harus selalu dilaksanakan secara terbuka diketahui oleh umum;

d. Peduli pada stakeholder: lembaga-lembaga dan seluruh proses pemerintah harus berusaha melayani semua pihak yang berkepentingan dengan adanya pemberian informasi secara terbuka, terbuka untuk open free suggestion, dan terbuka terhadap kritik yang merupakan partisipasi;

e. Berorientasi pada konsensus: tata pemerintahan yang baik menjembatani kepentingan-kepentingan yang berbeda demi terbangunnya suatu konsensus menyeluruh dalam hal apa yang terbaik bagi kelompokkelompok masyarakat, dan bila mungkin, konsensus dalam hal kebijakan-kebijakan dan prosedur-prosedur;

f. Kesetaraan: semua warga masyarakat mempunyai kesempatan memperbaiki atau mempertahankan kesejahteraan mereka;

g. Efektifitas dan efisiensi: proses-proses pemerintahan dan lembaga-lembaga membuahkan hasil sesuai kebutuhan warga masyarakat dan dengan menggunakan sumbersumber daya yang ada seoptimal mungkin;

h. Akuntabilitas: para pengambil keputusan di pemerintah, sektor swasta, dan organisasi masyarakat bertanggung jawab; baik kepada masyarakat maupun kepada lembaga-lembaga yang berkepentingan. Dalam penelitian hukum 
ini, dikaitkan dengan pengurusan pengelolaan keuangan negara yang dilakukan oleh bendahara.

Akuntabilitas dapat dibedakan ke dalam 3 jenis besar, yaitu akuntabilitas politik, akuntabilitas ekonomi, dan akuntabilitas hukum. "Akuntabilitas hukum mengandung pengertian rakyat harus memiliki keyakinan bahwa unit-unit pemerintahan atau satuan kerja pemerintahan dapat dipertanggungjawabkan secara hukum atas segala tindakannya."9

Ketentuan dalam Pasal 10 ayat (1) UndangUndang Nomor 30 Tahun 2014 tentang Administrasi Pemerintahan, asas-asas umum pemerintahan yang baik (AUPB), dapat diidentifikasi menjadi 8 asas, yaitu: asas kepastian hukum, asas kemanfaatan, asas ketidakberpihakan, asas kecermatan, asas tidak menyalahgunakan kewenangan, asas keterbukaan, asas kepentingan umum, dan asas pelayanan yang baik.

Dari sudut pandang hukum administrasi, konsep good governance berkaitan dengan aktivitas pelaksanaan fungsi untuk menyelenggarakan kepentingan umum. Good governance berkenaan dengan penyelenggaraan tiga tugas dasar pemerintah yaitu:

1. Menjamin keamanan setiap orang dan masyarakat (to guarantee the security of all persons and society itself);

2. Mengelola suatu struktur yang efektif untuk sektor publik, sektor swasta dan masyarakat (to manage an effective framework for the public sector, the private sector and civil society);

3. Memajukan sasaran ekonomi, sosial dan bidang lainnya dengan kehendak rakyat (to promote economic, social and other aims in accordance with the wishes of the population). ${ }^{10}$

Dengan demikian dapat dikatakan good governance sebagai suatu kondisi ideal dimana terbangun relasi sinergis dan sejajar antara dunia usaha (sektor swasta), pemerintah dan masyarakat sipil, sebagai sebuah upaya mewujudkan penyelenggaraan pemerintahaan yang bersih, responsif, dilaksanakan dan dipertangungjawabkan berdasarkan peraturan yang berlaku.

9 Philipus M. Hadjon et al., Hukum Administrasi dan Good Governance (Jakarta, Universitas Trisakti, 2010), hlm. 41.

10 Ibid., hlm. 9-10.

\section{METODOLOGI PENELITIAN}

\subsection{Tipe Penelitian}

Penelitian ini merupakan penelitian hukum. Menurut Marzuki, "Penelitian hukum adalah merupakan suatu proses ilmiah untuk mencari pemecahan atas isu hukum yang muncul dengan tujuan untuk memberikan preskripsi mengenai apa yang seyogyanya atas isu hukum yang muncul tersebut."11 Dan “... penelitian hukum dilakukan untuk menghasilkan argumentasi, teori atau konsep baru sebagai preskripsi dalam meyelesaikan masalah yang dihadapi."12 Adapun langkah-langkah dari penelitian hukum antara lain:

1. Mengidentifikasi fakta hukum dan mengeliminir hal-hal yang tidak relevan untuk menetapkan isu hukum yang hendak dipecahkan;

2. Pengumpulan bahan-bahan hukum dan sekiranya dipandang mempunyai relevansi juga bahan-bahan non-hukum;

3. Melakukan telaah atas isu hukum yang diajukan berdasarkan bahan-bahan yang telah dikumpulkan;

4. Menarik kesimpulan dalam bentuk argumentasi yang menjawab isu hukum;

5. Memberikan preskripsi berdasarkan argumentasi yang telah dibangun di dalam kesimpulan. ${ }^{13}$

\subsection{Pendekatan Masalah}

"Dalam suatu penelitian hukum diperlukan metode pendekatan yang dimaksudkan untuk mendapatkan informasi dari berbagai aspek mengenai isu hukum yang sedang dicoba untuk dicari jawabnya."14 Pendekatan masalah yang digunakan dalam penelitian hukum ini adalah pendekatan perundang-undangan (statute approach) dan pendekatan konseptual (conceptual approach).

Pendekatan perundang-undangan (statute approach) yaitu memecahkan jawaban atas rumusan masalah yang “... dilakukan dengan menelaah semua undang-undang dan regulasi yang

11 Peter Mahmud Marzuki, Penelitian Hukum, Yuridika, Volume 16 No. 2, Maret 2001, hlm. 103.

12 Peter Mahmud Marzuki, Penelitian Hukum, Cetakan ke-3, Edisi Pertama, (Jakarta, Kencana Prenada Media Group, 2009), hlm. 35.

13 Ibid., hlm. 170.

14 Peter Mahmud Marzuki (2001), Op.Cit., hlm. 93. 
bersangkut paut dengan isu hukum yang sedang ditangani." 15

Pendekatan perundang-undangan (statute approach) dalam penelitian ini antara lain UndangUndang Nomor 17 Tahun 2003 Keuangan Negara, Undang-Undang Nomor 1 Tahun 2004 tentang Perbendaharaan Negara, Undang-Undang Nomor 15 Tahun 2004 tentang Pemeriksaan Pengelolaan dan Tanggung jawab Keuangan Negara dan Undang-Undang Nomor 30 Tahun 2014 tentang Administrasi Pemerintahan.

Pendekatan konseptual (conceptual approach) yaitu memecahkan jawaban atas rumusan masalah yang diajukan dengan merujuk pada prinsipprinsip hukum yang relevan. "Pendekatan konseptual beranjak dari pandangan-pandangan dan doktrin-doktrin yang berkembang di dalam ilmu hukum." 16 Pendekatan konseptual ini penting untuk mengetahui konsep bendahara dan konsep good governance yang menjadi fokus pembahasan dalam penelitian hukum ini.

\subsection{Sumber Bahan Hukum}

Bahan hukum dalam penelitian ini terdiri atas bahan hukum primer dan bahan hukum sekunder. Dalam penelitian ini bahan hukum yang dijadikan rujukan meliputi:

\section{a. Bahan Hukum Primer}

"Bahan hukum primer merupakan bahan hukum yang bersifat autoritatif artinya mempunyai otoritas."17 Bahan hukum tersebut merupakan norma yang bersifat mengikat. Sumber bahan hukum primer dalam penelitian ini antara lain:

- Undang-Undang Dasar Negara Republik Indonesia 1945;

- Undang-Undang Nomor 31 Tahun 1999 Tentang Pemberantasan Tindak Pidana Korupsi;

- Undang-Undang Nomor 17 Tahun 2003 tentang Keuangan Negara;

- Undang-Undang Nomor 1 Tahun 2004 tentang Perbendaharaan Negara;

- Undang-Undang Nomor 15 Tahun 2004 tentang Pemeriksaan Pengelolaan dan Tanggung jawab Keuangan Negara;

- Undang-Undang Nomor 15 Tahun 2006 tentang Badan Pemeriksa Keuangan Negara;

- Undang-Undang Nomor 14 tahun 2008 tentang Keterbukaan Informasi Publik;

15 Ibid., hlm. 93.

16 Ibid., hlm. 95.

17 Ibid., hlm. 141.
- Undang-Undang Nomor 12 Tahun 2011 tentang Pembentukan Peraturan Perundang-undangan;

- Undang-Undang Nomor 30 Tahun 2014 tentang Administrasi Pemerintahan.

b. Bahan Hukum Sekunder

Bahan hukum sekunder adalah “... bahanbahan sekunder berupa semua publikasi tentang hukum yang bukan merupakan dokumen-dokumen resmi." 18 Bahan hukum tersebut berfungsi untuk menjelaskan bahan hukum primer dan tidak bersifat autoritatif. Bahan hukum sekunder sebagai penunjang bahan hukum primer meliputi doktrin, buku-buku teks, artikel, kamus hukum, jurnaljurnal hukum, makalah, data yang didapat dengan mengunduh melalui internet yang ada kaitannya dengan permasalahan yang dibahas.

\subsection{Prosedur Pengumpulan Bahan Hukum}

Bahan hukum primer dan sekunder akan diinventarisasi dan diidentifikasi untuk kemudian digunakan dalam menganalisis permasalahan yang berhubungan dengan penelitian ini. Bahan hukum primer dikumpulkan dengan metode inventarisasi dan kategorisasi, dan bahan hukum sekunder dikumpulkan dengan sistem kartu catatan (card system) yang pelaksanaannya dilakukan dengan sistematis, logis, dan kritis.

\section{HASIL PENELITIAN}

\subsection{Jabatan Fungsional Dalam Konteks Kedudukan Bendahara}

Definisi jabatan menurut Algra dan Janssen adalah sebagai berikut: "Een ambt is een instituut met eigen werkkring waaraan bij de instelling duurzaam en welomschreven taak en bevoegdheden zijn verleend." 19 (jabatan adalah suatu lembaga dengan lingkup pekerjaan sendiri yang dibentuk untuk waktu lama dan kepadanya diberikan tugas dan wewenang).

Menurut Bagir Manan, "Jabatan adalah lingkungan pekerjaan tetap yang berisi fungsifungsi tertentu yang secara keseluruhan mencerminkan tujuan dan tata kerja suatu organisasi." 20 Dengan kata lain, "jabatan adalah

18 Ibid.

19 N.E. Algra en H.C.J.G. Janssen, Rechtsingang, Een Orientasi in Het Recht (Groningen, H.D. Tjeenk Willink bv, 1974), hlm. 175.

20 Bagir Manan, Pengisian Jabatan Presiden Melalui (dengan) Pemilihan Langsung, Makalah, hlm. 1. 
suatu lingkungan pekerjaan tetap yang diadakan dan dilakukan guna kepentingan negara." 21

Jabatan dalam lingkungan birokrasi pemerintah adalah jabatan karier. Jabatan karier dapat dibedakan dalam 2 jenis yaitu jabatan struktural dan jabatan fungsional. Dimana, jabatan struktural adalah jabatan yang secara tegas ada dalam struktur organisasi. Sedang jabatan fungsional adalah jabatan yang tidak secara tegas disebutkan dalam struktur organisasi, tetapi dari sudut fungsinya diperlukan oleh organisasi, seperti: peneliti, dokter, pustakawan dan lain-lain yang serupa dengan itu.

Menurut ketentuan Pasal 10 ayat (3) UU Perbendaharaan Negara, diatur bahwa "Bendahara Penerimaan dan Bendahara Pengeluaran sebagaimana dimaksud pada ayat (1) dan ayat (2) adalah Pejabat Fungsional."

Menurut ketentuan dalam Pasal 1 angka 1 Peraturan Pemerintah Republik Indonesia Nomor 16 Tahun 1994 tentang Jabatan Fungsional Pegawai Negeri Sipil, yang dimaksud dengan Jabatan Fungsional Pegawai Negeri Sipil adalah: “... kedudukan yang menunjukkan tugas, tanggung jawab, wewenang dan hak seseorang Pegawai Negeri Sipil dalam suatu satuan organisasi yang dalam pelaksanaan tugasnya didasarkan pada keahlian dan/ atau ketrampilan tertentu serta bersifat mandiri."

UU Perbendaharaan Negara telah terbit sejak tahun 2004, namun sampai saat ini dalam prakteknya bendahara belum dikategorikan sebagai jabatan fungsional seperti halnya jabatan guru, dosen, atau peneliti. Sebagai konsekuensinya, bendahara tidak mendapatkan tunjangan jabatan. Hal ini mengakibatkan keadaan ideal yang diinginkan oleh undang-undang tidak sepenuhnya dapat terwujud.

Amanat UU Perbendaharaan Negara mengenai fungsionalisasi jabatan bendahara sudah mendesak untuk segera direalisasikan. Dimana, Pasal 70 ayat (1) UU Perbendaharaan Negara memberikan tenggang waktu sampai 1 (satu) tahun, yaitu "Jabatan fungsional bendahara sebagaimana dimaksud dalam Pasal 10 dibentuk selambatlambatnya 1 (satu) tahun sejak Undang-Undang ini diundangkan."

Waktu satu tahun tersebut telah lewat, namun bukan berarti kewajiban Pemerintah untuk merealisasikannya menjadi gugur. Hal ini justru harus memacu Pemerintah untuk segera merealisasikannya.

21 E. Utrecht, Pengantar Hukum Administrasi Negara Indonesia (Surabaya, Pustaka Tinta Mas, 1988), hlm. 200.
Fungsionalisasi jabatan bendahara ingin menunjukkan adanya kemandirian posisi bendahara, memberi indikasi bahwa bendahara adalah personal yang mandiri dan memiliki kedudukan kuat dalam hal pelaksanaan anggaran negara.

Reformasi keuangan negara menuntut Menteri Keuangan selaku Chief Financial Officer melakukan perbaikan dan penataan dalam segala hal. Pembenahan dilakukan baik terhadap peraturan perundang-undangan, organisasi, maupun para pegawai di lingkungan Kementerian Keuangan. Bersamaan dengan prioritas reformasi keuangan negara, program fungsionalisasi jabatan bendahara merupakan bagian dari prioritas dimaksud. Program fungsionalisasi jabatan bendahara yang bermuara pada pengelolaan keuangan yang akuntabel, transparan, dan profesional di tingkat satuan kerja perlu mendapatkan prioritas untuk segera diwujudkan. Bahkan fungsionalisasi jabatan bendahara pada akhirnya juga akan mendukung terwujudnya program prioritas pengelolaan keuangan negara lainnya.

Pada masa kolonial, sistem administrasi keuangan mengenal 2 (dua) kelompok pejabat, yaitu kelompok penguasa dan kelompok penerima kuasa atau yang lebih populer disebut bendahara. Kelompok pertama terdiri dari para pejabat yang memegang fungsi otorisasi dan fungsi ordonansi (pengelolaan administratif/ administratief beheer), sedangkan kelompok kedua merupakan pejabat yang memegang fungsi komtabel (pengelolaan kebendaharaan/ comptabel beheer). Kedua kelompok tersebut terdapat di setiap kementerian.

Pengelolaan administratif meliputi kewenangan otorisasi (beschikkings bevoegheid) dan kewenangan ordonansi (ordonnancerings bevoegheid). Pengertian kewenangan otorisasi adalah: “.... kekuasaan yang bersumber pada kewenangan untuk mengesahkan atau menguasai anggaran yang menimbulkan kewenangan pembebanan (uang) negara ...", sedangkan yang dimaksudkan dengan kewenangan ordonansi adalah: ".... kekuasaan untuk menetapkan kuasa bayar atau menguji kebenaran pembayaran ...."22

Sedangkan yang dimaksud dengan pengelolaan kebendaharaan yaitu: "pelaksanaan pembayaran yang dilakukan berdasarkan surat perintah pembayaran yang dikeluarkan oleh ordonator, serta atas pembayaran mana diwajibkan bagi mereka yang bertindak dalam pengelolaan kebendaharaan untuk mempertanggungjawabkannya kepada BEPEKA ...." 23

22 Arifin P. Soeria Atmadja, Op.Cit., hlm. 70.

23 Ibid., hlm. 71. 
Sebelum berlakunya UU Keuangan Negara dan UU Perbendaharaan Negara, kewenangan ordonator sepenuhnya berada di tangan Menteri Keuangan. Namun sejak diberlakukannya kedua undang-undang tersebut, kewenangan ordonator diberikan kepada kementerian/ lembaga, sehingga kementerian/ lembaga sepenuhnya memegang kewenangan pengurusan administratif/ umum yaitu memegang kewenangan otorisator dan ordonator. Sedangkan Menteri Keuangan memegang kewenangan pengurusan khusus/ kebendaharaan.

Menteri Keuangan selaku Bendahara Umum Negara tidak hanya sebagai kasir yang hanya berwenang melaksanakan penerimaan dan pengeluaran negara tanpa berhak menilai kebenaran penerimaan dan pengeluaran tersebut. Menteri Keuangan selaku Bendahara Umum Negara adalah pengelola keuangan dalam arti seutuhnya yaitu berfungsi sekaligus sebagai kasir, pengawas keuangan dan manajer keuangan. Tujuan adanya pemisahan secara tegas kewenangan administratif dan kewenangan kebendaharaan adalah untuk meningkatkan akuntabilitas dan menjamin terselenggaranya saling uji (check and balance) dalam proses pelaksanaan anggaran.

Konsep pemisahan kewenangan yang dikemukakan tersebut di atas, dapat digambarkan melalui tabel berikut:

Tabel 1. Konsep Pemisahan Kewenangan Dalam Pelaksanaan Anggaran Belanja Negara

Pemisahan Kewenangan Dalam Pelaksanaan Anggaran Belanja Negara

\begin{tabular}{|c|c|c|c|c|}
\hline \multicolumn{3}{|c|}{$\begin{array}{c}\text { Menteri Teknis } \\
\text { Selaku Pengguna Anggaran }\end{array}$} & \multicolumn{2}{|c|}{$\begin{array}{l}\text { Menteri Keuangan } \\
\text { Selaku BUN }\end{array}$} \\
\hline $\begin{array}{l}\text { Pembuatan } \\
\text { Komitmen }\end{array}$ & $\begin{array}{c}\text { Pengujian } \\
\text { dan } \\
\text { Pembebanan }\end{array}$ & $\begin{array}{c}\text { Perintah } \\
\text { Pembayaran }\end{array}$ & Pengujian & $\begin{array}{l}\text { Pencairan } \\
\text { Dana }\end{array}$ \\
\hline \multicolumn{3}{|c|}{ Pengurusan Administratif } & \multicolumn{2}{|c|}{$\begin{array}{c}\text { Pengurusan } \\
\text { Kebendaharaan } \\
\text { (comptabel beheer) }\end{array}$} \\
\hline
\end{tabular}

Menurut Black's Law Dictionary, yang dimaksud dengan bendahara/ treasurer adalah: An organization's chief financial officer. The treasurer's duties typically include prudently depositing (or, if authorized, investing) and safeguarding the organization's funds and otherwise managing its finances; monitoring compliance with any applicable law relating to such finances and filing any required report; disbursing money as authorized; and reporting to the organization on the state of the treasury. Also termed finance officer; financial secretary; quartermaster. ${ }^{24}$

Menurut Pasal 1 angka 14 UU Perbendaharaan Negara, yang dimaksud dengan bendahara adalah "setiap orang atau badan yang diberi tugas untuk dan atas nama negara/ daerah, menerima, menyimpan, dan membayar/ menyerahkan uang atau surat berharga atau barang-barang negara/ daerah."

Beberapa hal penting terkait pengertian di atas:

a. Setiap Pegawai Negeri Sipil (PNS) dapat ditetapkan oleh Menteri/ Pimpinan Lembaga sebagai Bendahara satuan kerja untuk melaksanakan tugas kebendaharaan;

b. Tugas kebendaharaan meliputi: menerima, menyimpan, membayar/ menyerahkan dan mempertanggungjawabkan uang/ surat berharga/ barang yang berada di bawah pengawasannya;

c. Dalam melaksanakan tugasnya wajib melaksanakan/ menyelenggarakan pembukuan atas uang yang dikelolanya dan membuat laporan pertanggungjawaban.

Bendahara seringkali mengalami kesulitan dalam pelaksanaan tugas pekerjaannya. Beberapa contoh kesulitan yang dihadapi bendahara adalah sebagai berikut:

a. Bendahara sering mengalami kesulitan dalam menolak permintaan bayar yang diajukan oleh pimpinan (Kuasa Pengguna Anggaran/ KPA) walaupun permintaan tersebut tidak disertai dengan bukti-bukti pembayaran yang sah. Para bendahara secara struktural berada di bawah pimpinan kantor yang notabene adalah KPA. Daftar Penilaian Pelaksanaan Pekerjaan (DP3) sepenuhnya menjadi kewenangan pimpinan struktural bendahara. Pimpinan struktural dapat melakukan penggantian bendahara. Sementara itu, sampai saat ini masih cukup banyak pimpinan kantor yang belum/ kurang memahami peraturan perundang-undangan yang baru mengenai pengelolaan keuangan negara;

b. Tidak adanya reward/ imbalan yang memadai kepada bendahara dapat memicu tindakan yang bertentangan dengan norma dan etika. Di satu sisi para bendahara tidak mendapatkan tunjangan jabatan, sementara itu pada sisi yang lain mereka harus mempertaruhkan semua harta pribadinya jika melakukan tindakan yang merugikan negara. Saat ini para bendahara memang telah menerima honor,

24 Bryan A. Garner, ed., Black's Law Dictionary, Ninth Edition, (USA, West Publishing co.st. Paul Minn, 2009), hlm. 1640. 
namun sebuah jabatan tidak semata-mata diberikan kompensasi sebatas honor, tetapi juga menyangkut penghargaan, kemandirian, ataupun karier mereka. Konsekuensi dari sebuah jabatan fungsional tidak hanya pada adanya tunjangan jabatan, tetapi lebih dari itu;

c. Jika terjadi pemeriksaan keuangan baik oleh aparat pemeriksa internal maupun eksternal, bendahara selalu menjadi objek utama dan pertama untuk diperiksa. Bendahara harus mempertanggungjawabkan semua pengeluaran keuangan yang dikelolanya. Pada saat diperiksa, bendahara menghadapi tekanan secara mental, apalagi jika merasa pembukuan atau pengelolaan keuangannya ada yang tidak/ kurang benar. Bendahara harus menghadapi potensi risiko terhadap kemungkinan adanya kerugian negara. Jika pemeriksa menemukan kesalahan, hal ini akan menambah beban psikologis pada bendahara.

Jabatan fungsional pada hakekatnya adalah jabatan teknis yang tidak tercantum dalam struktur organisasi, namun sangat diperlukan dalam tugas-tugas pokok dalam organisasi pemerintah. Produk hukum yang mengatur pengangkatan seseorang dalam jabatan fungsional adalah Peraturan Pemerintah Republik Indonesia Nomor 40 Tahun 2010 tentang Perubahan Atas Peraturan Pemerintah Nomor 16 Tahun 1994 tentang Jabatan Fungsional Pegawai Negeri Sipil dan Peraturan Presiden Republik Indonesia Nomor 97 Tahun 2012 tentang Perubahan Atas Keputusan Presiden Republik Indonesia Nomor 87 Tahun 1999 tentang Rumpun Jabatan Fungsional Pegawai Negeri Sipil.

Salah satu penyebab kegagalan dalam pembentukan jabatan fungsional bendahara adalah kelemahan yang terdapat dalam mekanisme pelaksanaan survei penetapan angka kredit yang ditetapkan oleh Kementerian Pendayagunaan Aparatur Negara (Menpan) sebagai persyaratan dalam pembentukan jabatan fungsional.

Sesuai ketentuan yang ditetapkan oleh Menpan, pelaksanaan survei penetapan angka kredit yang akan digunakan sebagai pengukuran kinerja bagi pejabat fungsional, dilakukan dengan cara mengumpulkan data beban kerja per kegiatan yang dilakukan oleh para pegawai/ pejabat struktural. Padahal sebagaimana telah kita ketahui, terdapat perbedaan dalam sistem pembagian kerja antara para pegawai/ pejabat struktural dengan pejabat fungsional. Pembagian kerja di antara para pelaksana pada jabatan struktural biasanya ditetapkan secara fleksibel tergantung pada kebutuhan unit kerja yang bersangkutan dan jumlah tenaga kerja yang tersedia. Sedangkan, pembagian kerja untuk para pegawai dalam jabatan fungsional ditetapkan secara vertikal berdasarkan jenjang jabatannya, dimana masingmasing kegiatan tersebut mempunyai bobot nilai kredit yang ditetapkan dalam suatu peraturan Menpan. Di samping itu, untuk menghasilkan suatu produk dalam jabatan struktural seringkali dikerjakan secara kerjasama tim yang dipimpin dan dikoordinasikan oleh seorang pejabat eselon, sedangkan dalam jabatan fungsional suatu produk pada umumnya dikerjakan secara mandiri oleh seorang pejabat fungsional.

Dibandingkan dengan jabatan struktural pada umumnya yang penilaian kinerjanya dilakukan oleh pejabat atasannya dengan memperhatikan unsur-unsur penilaian yang telah ditetapkan dalam dokumen DP3 PNS, jabatan fungsional mempunyai sistem penilaian kinerja yang disebut angka kredit, yang dibuat berdasarkan aktivitas kegiatankegiatan yang telah dilakukan oleh pejabat fungsional yang bersangkutan dalam kurun waktu tertentu. Sebagaimana diatur dalam Pasal 1 angka 3 Peraturan Pemerintah Republik Indonesia Nomor 16 Tahun 1994 tentang Jabatan Fungsional Pegawai Negeri Sipil, bahwa "Angka Kredit adalah satuan nilai dari tiap butir kegiatan dan/ atau akumulasi nilai butir-butir kegiatan yang harus dicapai oleh pejabat fungsional dalam rangka pembinaan karier yang bersangkutan." Pada umumnya sistem penilaian kinerja berdasarkan angka kredit tersebut dinilai lebih obyektif dibandingkan dengan sistem penilaian kinerja yang hanya berdasarkan pada penilaian pejabat atasannya yang dituangkan dalam DP3.

Ketentuan dalam UU Perbendaharaan Negara menunjukkan bahwa kedudukan bendahara dalam pengelolaan keuangan negara menjadi semakin istimewa karena menjadi bagian dari pejabat perbendaharaan. Karena itu, jabatan bendahara tidak boleh dirangkap oleh Kuasa Pengguna Anggaran atau Kuasa Bendahara Umum Negara, hal tersebut sebagaimana diatur dalam Pasal 10 ayat (4) UU Perbendaharaan Negara.

Dalam UU Perbendaharaan Negara, bendahara merupakan jabatan fungsional. Hal tersebut, di samping ingin menunjukkan adanya kemandirian posisi bendahara juga ingin menunjukkan bahwa untuk menduduki jabatan tersebut dibutuhkan kemampuan dan profesionalisme yang tinggi. Tuntutan profesionalisme tersebut tergambar jelas pada beberapa ketentuan yang mengatur mengenai bendahara, antara lain:

1. Bendahara wajib menolak permintaan bayar yang tidak disertai bukti pengeluaran yang sah.

Pasal 21 ayat (4) UU Perbendaharaan Negara menyebutkan kewenangan ini sebagai berikut: "Bendahara Pengeluaran wajib menolak perintah bayar dari Pengguna Anggaran/ Kuasa Pengguna Anggaran apabila persyaratan pada 
ayat (3) tidak dipenuhi". Sedangkan persyaratan yang dimaksudkan pada ayat (3) tersebut adalah (a) kelengkapan perintah pembayaran yang diterbitkan oleh Pengguna Anggaran/ Kuasa Pengguna Anggaran, (b) kebenaran perhitungan tagihan yang tercantum dalam perintah pembayaran, dan (c) ketersediaan dana yang bersangkutan. Pasal ini menuntut agar bendahara pengeluaran memiliki independency atau kemandirian dalam tugas/ pekerjaannya. Perintah bayar dari Pengguna Anggaran/ Kuasa Pengguna Anggaran wajib ditolak jika perintah tersebut tidak lengkap atau tidak sesuai dengan ketentuan peraturan perundang-undangan walaupun secara struktural bendahara berada di bawah Pengguna Anggaran/ Kuasa Pengguna Anggaran.

2. Bendahara bertanggung jawab secara pribadi.

Hal ini merupakan warning yang cukup efektif bagi setiap bendahara. Pasal 21 ayat (5) UU Perbendaharaan Negara menegaskan secara jelas akan hal ini, "Bendahara Pengeluaran bertanggung jawab secara pribadi atas pembayaran yang dilaksanakannya". Atas dasar hal ini, bendahara dituntut untuk bekerja secara hati-hati. Sebab, kesalahan hitung ataupun kesalahan bayar akan menjadi tanggung jawabnya secara pribadi.

3. Bendahara dibatasi dalam kegiatan perdagangan.

Ketentuan dalam pasal 10 ayat (5) UU Perbendaharaan Negara mengatur bahwa "Bendahara Penerimaan/ Pengeluaran dilarang melakukan, baik secara langsung maupun tidak langsung, kegiatan perdagangan, pekerjaan pemborongan dan penjualan jasa atau bertindak sebagai penjamin atas kegiatan/ pekerjaan/ penjualan tersebut." Pasal ini menuntut seorang bendahara konsentrasi penuh dalam mengemban jabatannya, tanpa membuka kesempatan untuk melakukan pekerjaan tambahan di bidang perdagangan dan sejenisnya.

4. Jika terjadi kerugian negara yang dilakukan oleh bendahara maka pengenaan ganti kerugiannya langsung ditangani oleh BPK.

"Pengenaan ganti kerugian negara/ daerah terhadap bendahara ditetapkan oleh Badan Pemeriksa Keuangan", demikian disebutkan dalam Pasal 62 ayat (1) UU Perbendaharaan Negara. Penetapan oleh pihak eksternal (BPK) tentu berbeda secara psikologis maupun dampak yang akan ditanggung oleh bendahara yang bersangkutan.

Sejalan dengan pilar utama negara hukum, yaitu asas legalitas, maka berdasarkan prinsip ini tersirat bahwa wewenang pemerintahan berasal dari peraturan perundang-undangan, artinya sumber wewenang bagi pemerintah adalah peraturan perundang-undangan. Secara teoritik, kewenangan yang bersumber dari peraturan perundang-undangan tersebut diperoleh melalui tiga cara, yaitu: atribusi, delegasi dan mandat.

Jika dilihat dari sumber kewenangan yang diperoleh bendahara dalam melaksanakan kegiatannya, secara eksplisit bendahara melaksanakan kegiatannya berdasarkan delegasi yang diberikan oleh kementerian negara/ lembaga.

Menurut ketentuan dalam Pasal 1 angka 23 Undang-Undang Nomor 30 Tahun 2014 tentang Administrasi Pemerintahan, yang dimaksud dengan delegasi adalah "pelimpahan kewenangan dari Badan dan/ atau Pejabat Pemerintahan yang lebih tinggi kepada Badan dan/ atau Pejabat Pemerintahan yang lebih rendah dengan tanggung jawab dan tanggung gugat beralih sepenuhnya kepada penerima delegasi."

Dalam hal pelimpahan wewenang pemerintahan melalui delegasi ini terdapat syaratsyarat sebagai berikut:

a. Delegasi harus definitif dan pemberi delegasi (delegans) tidak dapat lagi menggunakan sendiri wewenang yang telah dilimpahkan itu;

b. Delegasi harus berdasarkan ketentuan peraturan perundang-undangan, artinya delegasi hanya dimungkinkan kalau ada ketentuan untuk itu dalam peraturan perundang-undangan;

c. Delegasi tidak kepada bawahan, artinya dalam hubungan hierarki kepegawaian tidak diperkenankan adanya delegasi;

d. Kewajiban memberikan keterangan (penjelasan), artinya delegans berhak untuk meminta penjelasan tentang pelaksanaan wewenang tersebut;

e. Peraturan kebijakan (beleidsregel), artinya delegans memberikan instruksi (petunjuk) tentang penggunaan wewenang tersebut. ${ }^{25}$

\subsection{Prinsip Good Governance Dalam Pengelolaan Keuangan Negara}

Wacana baru tentang good governance muncul setelah berbagai lembaga pembiayaan internasional mempersyaratkan good governance dalam berbagai program bantuannya. "Meskipun good governance populer di Indonesia namun hingga saat ini belum ada istilah baku dalam

25 Ridwan HR, Hukum Administrasi Negara, cetakan ke-8 (Jakarta: Raja Grafindo Persada, 2013), hlm. 105. 
bahasa Indonesia baik untuk governance maupun untuk good governance." 26

Menurut Ganie-Rochman, pengertian good governance memiliki empat unsur utama yaitu accountability, adanya kerangka hukum (rule of law), informasi dan transparansi. Dalam kaitannya dengan akuntabilitas, Hughes menegaskan bahwa "government organizations are created by the public, for the public, and need to be accountable to it". Dengan kata lain, organisasi pemerintah dibuat oleh publik dan karenanya perlu mempertanggungjawabkannya kepada publik. Brautigam membedakan akuntabilitas ke dalam 3 jenis besar, yaitu akuntabilitas politik, akuntabilitas ekonomi, dan akuntabilitas hukum. Akuntabilitas hukum mengandung pengertian bahwa rakyat harus memiliki keyakinan bahwa unit-unit pemerintahan atau satuan kerja pemerintahan dapat dipertanggungjawabkan secara hukum atas segala tindakannya. ${ }^{27}$

Diuraikan lebih lanjut oleh Daniri bahwa dalam penerapan good governance harus tercermin tiga karakteristik, yakni: Pertama, praktek good governance harus memberi ruang kepada pihak di luar penyelenggara negara untuk berperan optimal sehingga memungkinkan adanya sinergi antar berbagai pihak. Kedua, terkandung nilai-nilai dalam praktek good governance yang membuat penyelenggara negara maupun swasta dapat bekerja lebih efektif dalam mewujudkan kesejahteraan rakyat. Ketiga, praktek good governance adalah praktek bernegara yang bersih dan bebas dari korupsi serta berorientasi pada kepentingan publik. ${ }^{28}$

Dari sudut pandang hukum administrasi, konsep good governance berkaitan dengan aktivitas pelaksanaan fungsi untuk menyelenggarakan kepentingan umum. Good governance berkenaan dengan penyelenggaraan tiga tugas dasar pemerintah, yaitu:

1. Menjamin keamanan setiap orang dan masyarakat (to guarantee the security of all persons and society itself).

2. Mengelola suatu struktur yang efektif untuk sektor publik, sektor swasta dan masyarakat (to manage an effective framework for the public sector, the private sector and civil society).

3. Memajukan sasaran ekonomi, sosial dan bidang lainnya dengan kehendak rakyat (to promote

26 Philipus M. Hadjon et al., Op.Cit., hlm. 3.

27 Philipus M. Hadjon et al., Op.Cit., hlm. 40-41.

28 Mas Achmad Daniri, Sambutan Ketua Komite Nasional Kebijakan Governance, Pedoman Umum Good Public Governance, KNKG, Jakarta, 2008. economic, social and other aims in accordance with the wishes of the population). ${ }^{29}$

Oleh karena itu, dalam rangka menciptakan situasi kondusif untuk melaksanakan Good Public Governance (selanjutnya disingkat dengan GPG) diperlukan tiga pilar, yaitu negara, dunia usaha (sektor swasta) dan masyarakat.

Negara harus merumuskan dan menerapkan GPG sebagai pedoman dasar dalam melaksanakan fungsi, tugas dan kewenangannya. Negara juga berkewajiban untuk menciptakan situasi kondusif yang memungkinkan penyelenggara negara dan jajarannya melaksanakan tugasnya dengan baik. Negara diharapkan mampu menjalankan fungsinya, antara lain: menciptakan kondisi politik, ekonomi dan sosial yang stabil; membuat peraturan yang efektif dan berkeadilan; menyediakan public service yang efektif dan accountable; menegakkan Hak Asasi Manusia (HAM); melindungi lingkungan hidup; mengurus standar kesehatan dan standar keselamatan publik.

Dunia usaha (sektor swasta) harus merumuskan dan menerapkan good corporate governance (selanjutnya disingkat dengan GCG) dalam melakukan usahanya sehingga dapat meningkatkan produktivitas nasional. Dunia usaha juga berkewajiban untuk berpartisipasi aktif memberikan masukan dalam perumusan dan pelaksanaan peraturan perundang-undangan dan kebijakan publik yang berkaitan dengan sektor usahanya. Secara konkrit, sektor swasta harus melaksanakan fungsinya, antara lain: menjalankan industri, menciptakan lapangan kerja, menyediakan insentif bagi karyawan, meningkatkan standar hidup masyarakat, memelihara lingkungan hidup, menaati peraturan, transfer ilmu pengetahuan dan teknologi kepada masyarakat dan menyediakan kredit bagi pengembangan ekonomi kemasyarakatan.

Masyarakat harus melakukan kontrol sosial secara efektif terhadap pelaksanaan fungsi, tugas dan kewenangan negara. Masyarakat juga berkewajiban untuk berpartisipasi aktif memberikan masukan dalam perumusan dan pelaksanaan peraturan perundang-undangan dan kebijakan publik. Masyarakat dituntut untuk memiliki pengetahuan dan kemampuan agar dapat melaksanakan kontrol sosial secara sehat dan bertanggung jawab, dan meningkatkan konsolidasi sumberdaya agar dapat memberikan kontribusi secara maksmimal, sehingga hak-hak masyarakat dapat terlindungi dan terpenuhi.

Pengaturan dalam Pasal 3 ayat (1) UU Keuangan Negara mencantumkan bahwa asas-asas umum, yaitu: efisien, ekonomis, efektif, transparan,

29 Philipus M. Hadjon et al., Op.Cit, hlm. 9-10. 
dan bertanggung jawab dengan memperhatikan rasa keadilan dan kepatutan. Selanjutnya pada bagian penjelasan undang-undang tersebut disebutkan asas-asas umum lain yang dianut, yaitu: asas tahunan, asas universalitas, asas kesatuan, dan asas spesialitas maupun asas-asas baru. Dalam penjelasan diuraikan bahwa asas-asas yang dianut dalam UU Keuangan Negara adalah penjabaran aturan pokok yang telah ditetapkan dalam UUD 1945, dimana sebagian yang sudah lama dikenal tidak dicantumkan dalam batang tubuh (sebagai norma hukum) sedangkan yang baru (merupakan best practice) dicantumkan dalam batang tubuh undang-undang.

Dalam hal ini, terdapat beberapa asas yang dicantumkan dalam norma peraturan perundangundangan. Terkait dengan hal tersebut, Scholten mengemukakan bahwa sebuah asas hukum (rechtsbeginsel) bukanlah sebuah aturan hukum (rechtsregel). Untuk dapat dikatakan sebagai aturan hukum, sebuah asas hukum adalah terlalu umum sehingga ia atau bukan apa-apa atau berbicara terlalu banyak (of niets of veel te veel zeide). Penerapan asas hukum secara langsung melalui jalan subsumsi atau pengelompokkan sebagai aturan tidaklah mungkin, karena itu terlebih dulu perlu dibentuk isi yang lebih kongkrit. ${ }^{30}$

Indrati menyatakan bahwa "dalam pembentukan peraturan perundang-undangan yang berlaku saat ini terdapat kecenderungan untuk meletakkan asas-asas hukum atau asas-asas pembentukan undang-undang ke dalam salah satu pasal-pasal awal, atau dalam Bab Ketentuan Umum." 31 Apabila hal tersebut dilakukan, maka hal itu tidaklah sesuai dengan pendapat Scholten di atas, atau dengan perkataan lain peraturan perundang-undangan tersebut sudah menjadikan suatu asas hukum atau asas pembentukan peraturan perundang-undangan menjadi suatu norma hukum. Sebagai suatu norma hukum hal tersebut akan berakibat adanya suatu sanksi apabila asas tersebut tidak dipenuhi atau tidak dilaksanakan.

Berkaitan dengan pelaksanaan prinsip-prinsip good governance berarti mempertegas arti pentingnya penerapan prinsip-prinsip good governance, namun sebaiknya asas-asas yang dimasukkan harus diuraikan lebih lanjut dengan jelas di dalam pasal-pasal undang-undang dan dijelaskan pada bagian penjelasan. Selain itu dalam peraturan yang ada, belum diatur tentang sanksi

30 Maria Farida Indrati, Ilmu Per-Undang-Undangan: Jenis, Fungsi, dan Materi Muatan (Yogyakarta: Kanisius, 2007), hlm. 253.

31 Ibid., hlm. 264-265. apabila asas-asas yang diterapkan sebagai norma tersebut tidak dilaksanakan.

Pembayaran belanja pemerintah pusat dapat dilakukan dengan cara pembayaran langsung (LS) atau tunai. Pembayaran langsung (LS) adalah dengan cara pemindahbukuan dari rekening kas negara ke rekening pihak ketiga/ penyedia barang melalui KPPN berdasarkan Surat Perintah Membayar (SPM) yang diajukan oleh Kuasa Pengguna Anggaran (KPA). Cara kedua adalah dengan tunai atau penerbitan cek oleh bendahara pengeluaran kepada pihak ketiga/ penyedia barang yang dananya berasal dari Uang Persediaan (UP) yang dikelola oleh bendahara.

Dari mekanisme pelaksanaan pembayaran belanja dapat dilihat bahwa dalam proses pelaksanaan anggaran belanja terdapat interaksi antara unsur-unsur dalam good governance, yaitu masyarakat, swasta, dan pemerintah. Swasta dan masyarakat menyerahkan barang/ jasa kepada pemerintah dan sekaligus menerima pelayanan publik yang dilaksanakan oleh instansi pemerintah. Dengan kata lain, dalam pelaksanaan anggaran belanja, penerapan prinsip partisipasi masyarakat dan swasta mutlak diperlukan karena tidak mungkin pemerintah memproduksi sendiri kebutuhan pengadaan barang dan jasa.

Good governance dalam konteks pengelolaan keuangan negara tidak boleh identik dengan proses pencairan anggaran yang lama dan rumit, tetapi harus diwujudkan dalam proses yang tepat waktu dan relatif sederhana dengan tetap memperhatikan asas kepatutan dan kepantasan.

\section{KESIMPULAN DAN SARAN}

\subsection{Kesimpulan}

Berdasarkan uraian di atas, penulis membuat kesimpulan sebagai berikut:

a. Jabatan fungsional adalah kedudukan yang menunjukkan tugas, tanggung jawab, wewenang, dan hak seorang Pegawai Negeri Sipil dalam suatu satuan organisasi yang dalam pelaksanaan tugasnya didasarkan pada keahlian dan/ atau ketrampilan tertentu serta bersifat mandiri. Dimana, sampai saat ini dalam prakteknya jabatan bendahara belum dikategorikan sebagai jabatan fungsional seperti halnya jabatan guru, dosen, dan peneliti. Sebagai konsekuensinya, bendahara tidak mendapatkan tunjangan jabatan. Hal ini mengakibatkan keadaan ideal yang diinginkan oleh undang-undang tidak sepenuhnya dapat terwujud;

b. Good governance merupakan suatu kondisi ideal dimana terbangun relasi sinergis dan sejajar antara dunia usaha (sektor swasta), pemerintah dan masyarakat sipil, sebagai 
sebuah upaya untuk mewujudkan penyelenggaraan pengelolaan keuangan negara yang bersih, responsif, dilaksanakan dan dipertangungjawabkan berdasarkan peraturan yang berlaku. Dimana, prinsip transparansi dan akuntabilitas dalam pengelolaan keuangan negara bersumber pada Pasal 23 ayat (1) UUD 1945. Pemakaian kata "terbuka" dan "bertanggung jawab" dalam Pasal 23 ayat (1) UUD 1945 tersebut mencerminkan bahwa sejak awal sudah ada kesadaran dan harapan dari pembuat undangundang akan pentingnya penerapan good governance dalam pengelolaan keuangan negara.

\subsection{Saran}

Berdasarkan pembahasan atas permasalahan di atas, maka diberikan saran sebagai berikut:

a. Ketentuan Pasal 10 ayat (3) UU Perbendaharaan Negara mengatur adanya fungsionalisasi jabatan bendahara, maka diharapkan agar pembentukan jabatan fungsional bagi bendahara harus segera dilaksanakan, sehingga kedudukan maupun tanggung jawabnya menjadi jelas dan keadaan ideal yang diinginkan oleh undang-undang sepenuhnya dapat terwujud. Karena jabatannya yang bersifat fungsional, maka bendahara mempunyai tanggung jawab secara pribadi terhadap pembayaran yang dilaksanakannya, sehingga jabatan bendahara tidak dapat dirangkap oleh pejabat lainnya;

b. Perlu disusun suatu peraturan teknis tentang penerapan prinsip-prinsip good governance dalam pengelolaan keuangan negara yang mengacu pada pedoman umum Good Public Governance (GPG) untuk meningkatkan transparansi dan akuntabilitas informasi anggaran dan mendorong partisipasi masyarakat. Dimana, kesejahteraan rakyat diharapkan akan meningkat seiring dengan meningkatnya partisipasi masyarakat dalam pelaksanaan anggaran belanja pemerintah pusat.

\section{IMPLIKASI DAN KETERBATASAN}

Berdasarkan uraian di atas, penulis menemukan bahwa:

a. Dari sisi teoritis, penelitian ini diharapkan dapat memberikan pengembangan pemikiran terhadap kedudukan bendahara, terutama sesudah diundangkannya UU Perbendaharaan Negara serta landasan pemikiran yang melandasi pemberian jabatan fungsional bagi bendahara;

b. Dari sisi praktis, hendaknya pembentukan jabatan fungsional bagi bendahara harus segera dilaksanakan, sehingga kedudukan maupun tanggung jawabnya menjadi jelas dan keadaan ideal yang diinginkan oleh undangundang sepenuhnya dapat terwujud.

\section{DAFTAR PUSTAKA (REFERENCES)}

Achir, M.N. Azny. (1975). Masalah Pengurusan Keuangan Negara, Yulianti, Bandung.

Algra, N.E. en H.C.J.G. Janssen. (1974). Rechtsingang, Een Orientasi in Het Recht, H.D. Tjeenk Willink bv, Groningen.

Atmadja, Arifin P. Soeria. (1986). Mekanisme Pertanggungjawaban Keuangan Negara, PT Gramedia, Jakarta.

Black, Henry Campbell. (1979). Black's Law Dictionary with Pronunciations, Fifth Edition, West Publishing co.st. Paul Minn, USA.

Bohari, H. (1995). Hukum Anggaran Negara, Raja Grafindo Persada, Jakarta.

Daniri, Mas Achmad. (2008). Sambutan Ketua Komite Nasional Kebijakan Governance, Pedoman Umum Good Public Governance, Artikel, KNKG, Jakarta.

Efendi, Sofian. (2005). Membangun Budaya Birokrasi untuk Good Governance. Lokakarya Reformasi Birokrasi, Departemen Pemberdayaan Aparatur Negara, Jakarta.

Garner, Bryan A., ed. (2009). Black's Law Dictionary, Ninth Edition, West Publishing co.st. Paul Minn, USA.

Hadjon, Philipus M. et al. (2010). Hukum Administrasi dan Good Governance, Universitas Trisakti, Jakarta.

HR, Ridwan. (2013), Hukum Administrasi Negara, Cetakan ke-8, RajaGrafindo Persada, Jakarta.

Indrati, Maria Farida. (2007). Ilmu Per-UndangUndang-an: Jenis, Fungsi, dan Materi Muatan, Kanisius, Yogyakarta.

Manan, Bagir. (1998). Pengisian Jabatan Presiden Melalui (dengan) Pemilihan Langsung, makalah, Jakarta.

Marzuki, Peter Mahmud. (2001). Penelitian Hukum, Yuridika, Volume 16, No. 2.

Marzuki, Peter Mahmud. (2009). Penelitian Hukum, Cetakan ke-3, Edisi Pertama, Kencana Prenada Media Group, Jakarta.

Thaib, Dahlan, Jazim Hamidi, dan Ni'matul Huda. (2006). Teori dan Hukum Konstitusi, Raja Grafindo Persada, Jakarta. 
Halaman 34 Febie Saputra

Utrecht, E. (1988). Pengantar Hukum Administrasi Negara Indonesia, Pustaka Tinta Mas, Penyelenggaraan Pemerintahan Daerah, Edisi II, Fokusmedia, Bandung. 